\title{
ENGINEERING DESIGN PROCESS PADA PERANCANGAN TRANSPORTASI PERSONAL DI DALAM LINGKUNGAN UNIVERSITAS
}

\author{
Deny Nusyirwan \\ Program Studi Teknik Elektro, Fakultas Teknik, Universitas Maritim Raja Ali Haji (UMRAH) \\ Jalan Politeknik Senggarang, Tanjungpinang 29100, Indonesia \\ E-mail: denynusyirwan@umrah.ac.id
}

\begin{abstract}
Abstrak
Universitas merupakan tempat mahasiswa mengikuti kegiatan belajar dan kegiatan non formal lainnya. Dengan semakin berkembangnya cabang ilmu pengetahuan, tidak jarang mahasiswa yang belajar ilmu teknik, akan mengikuti perkuliahan di fakultas lain atau mengikuti seminar-seminar yang diadakan oleh universitas atau organisasi mahasiswa di lingkungan kampus. Dari hasil observasi secara langsung, dapat ditemukan masalah utama yaitu mobilitas internal kampus, seperti terlambat mengikuti perkuliahan lanjutan akibat jarak dari satu lokasi perkuliahan ke lainnya yang cukup jauh karena tidak tersedianya transportasi yang memadai di lingkungan internal kampus atau ketinggalan bus shuttle karena terlambat sampai di lokasi pemberhentian bus. Dalam penelitian ini akan dititik beratkan pada transportasi pribadi didalam universitas yang nyaman dan selalu tersedia serta mudah dioperasikan. Penelitian dititik beratkan dengan mengikuti proses desain rekayasa dari observasi hingga pembuatan purwarupa sederhana untuk mendapatkan pengalaman dari calon pengguna.
\end{abstract}

Kata kunci : mobiltas, didalam kampus, bus shuttle, pemberhentian bus

\begin{abstract}
The University is a place for students to take part in learning activities and other non-formal activities. With the growing branch of science, it is not uncommon for students who study engineering, will take lectures in other faculties or attend seminars held by universities or student organizations on campus. From the results of direct observation, it can be found the main problem is the internal mobility of the campus, such as being late to follow lectures due to the distance from one lecture location to another which is quite far due to unavailability of adequate transportation in the campus or missed the shuttle bus due to being late to the location of the bus stop. In this study will be emphasis on the university's internal personal transportation which is comfortable and always available and easy to operate. The research focused on the engineering design process from observation and bulding simple prototypes to gain experience from the prospective users.
\end{abstract}

Key words : mobility, internal campus, shuttle bus, bus stop

\section{PENDAHULUAN}

Seiring dengan semakin berkembangnya sistem transportasi darat, maka diikuti juga dengan permasalahan emisi gas buang kendaraan. Menurut European Environment Agency (EEA) bahwa kendaraan pribadi yang menggunakan bahan bakar fosil akan memilliki dampak langsung terhadap ekonomi dan lingkungan dibanding dengan moda transportasi lainnya, oleh sebab itu pemanfaatan transportasi publik sangat dianjurkan ketika bepergian dalam rangka menurunkan tingkat pencemaran lingkungan, mengurangi kemacetan dan meningkatkan keamanan didalam berkendara. [1].
Dengan mendorong industri untuk menciptakan transportasi publik yang ramah lingkungan dan penggunaan mobil secara bersama (car sharing), pemerintah berusaha mendorong masyarakat untuk mengurangi bepergian dengan menggunakan transportasi personal. Selain itu perancangan aplikasi dengan pola pendekatan kebutuhan pengguna (user centric approach) untuk membantu pengguna merencanakan penggunaan transportasi umum dan pribadi dengan baik, dan sesuai kebutuhan yang berbasiskan sustainability dan energy efficient [2]. Penggunaan sepeda bertenaga listrik (e-bike) juga berpotensi untuk menggantikan bersepada secara konvensional dan perjalanan jarak dekat yang seharusnya mempergunakan mobil disela keterbatasan teknologi baterai dan jsangat baik

51 Nusyirwan, Deny; Engineering Design Process Pada Perancangan Transportasi Personal Di Dalam Lingkungan Universitas 
untuk mempromosikan kesehatan kepada pengendara yang ingin bepergian sendiri. [3]

Mobilitas berbasiskan mobil (car based mobility) seperti kendaraan listrik dan klub mobil adalah mobiltas masa depan yang merupakan solusi untuk mengurangi emisi pada bidang transportasi darat. Di negara Inggris, peminatan terhadap kendaraan listrik lebih besar karena tidak ada emisi gas buang yang dihasilkan, namun karena masih mobilitas berbasiskan mobil, jadi masih perlu diadakan penelitian lanjut terkait pengurangan emisi gas buang rumah kaca [4] Berbagai kebijakan oleh pemerintah swedia seperti pembatasan izin kepemilikan surat izin mengemudi dan anjuran untuk mengurangi perjalanan jauh dengan menggunakan kendaraan adalah merupakan cara untuk mengurangi pola hidup yang tergantung terhadap mobil [5]. Oleh sebab itu, bentuk sistem transportasi masa depan yang diinginkan adalah sistem transportasi yang dapat mengurangi eksternalitas negatif terhadap lingkungan dan sosial di masa depan [6].

Sebuah alternatif yang menarik untuk pemilik mobil yang masih mempergunakan bahan bakar fosil adalah Plug in Hybrid Electric Vehicle (PHEV), jenis kendaraan listrik hibrida yang menggabungkan mesin bensin atau diesel dengan motor listrik dan baterai besar yang dapat diisi ulang dengan menghubungkannya ke outlet listrik atau stasiun pengisian daya kendaraan listrik. Namun beberapa hal seperti biaya untuk kepemilikan yang tinggi dan jarak tempuh kendaraan yang masih terbatas masih menjadi hambatan utama didalam perkembangan kendaraan ramah lingkungan tersebut[7].

Penggunaan kendaraan pribadi bertenaga listrik (Personal Electric Vehicle) yang meningkat tentu akan memiliki dampak terhadap menurunnya polusi udara terutama di daerah perkotaan dan kebutuhan bahan bakar fosil serta perubahan iklim. Kesuksesan dari PEV ini sebagian besar masih tergantung dengan infrastruktur yang tersedia untuk pengisian kembali baterai. Oleh sebab itu perlu direncanakan jumlah dan lokasi yang sesuai untuk pendirian stasiun pengisian serta teknologi yang memungkinkan pengisian apabila proses pengisian dilakukan dalam jumlah besar [8]. Dengan teknologi yang ada pada saat ini, waktu pengisian energi pada baterai sudah hampir mendekati waktu yang dibutuhkan untuk pengisian bahan bakar konvensional.[9]

Saat ini transportasi darat yang bersifat personal masih tetap menjadi pilihan untuk bepergian, dengan alasan kenyamanan dan fleksibilitas. Oleh sebab itu perusahaan yang bergerak di industri otomotif berusaha meluncurkan transportasi personal dengan inovasi berbasiskan teknologi-teknologi ramah lingkungan.
Secara teknik Personal Electric Vehicle (PEV) sangat memungkinkan untuk direalisasikan, namun masih perlu menyesuaikan dengan kriteria dan kebutuhan pengguna seperti faktor keamanan, kenyamanan ketika berkendara dan cuaca. Selain itu diperlukan infrastruktur yang mendukung keamanan untuk pengendara [10] Satu hal yang juga diharapkan adalah energi listrik pada bateri yang dipergunakan oleh PEV kedepannya dapat dapat disalurkan ke falisitas yang memanfaatkan tenaga listrik [11].

Dari hasil analisa penggunaan car sharing dengan penggunaan kendaraan secara mengambang (Free-floating Car Sharing) pada 12 kota di eropa dan amerika, dari segi waktu dan pola daapt ditemukan bahwa kendaraaan bertenaga listrik lebih dominan dipergunakan untuk jarak dekat, sedangkan kendaraan konvensional lebih banyak dipergunakan untuk jarak jauh. Selain itu kebanyakan pengendara menggunakan untuk perjalanan satu arah dengan masa peminjaman sebagian besar 30 menit. Penggunaan kendaraan secara mengambang adalah penggunaan kendaraan yang memungkinkan pengendara mempergunakan mobil dimana saja dan kapan saja, dan dapat meninggalkan kendaraan tersebut dimana saja didalam daerah home.[12]

Universitas merupakan tempat mahasiswa menimba ilmu pengetahuan. Pengetahuan formal melalui pembelajaran di dalam kelas atau non formal dengan menghadiri seminar atau aktivitas lain di lingkungan universitas. Dan tidak jarang mahasiswa dengan latar belakang ilmu teknik akan mengikuti perkuliahan non teknik di fakultas lain. Didalam penelitian ini, dapat ditemukan permasalahan utama yang timbul yaitu mobilitas mahasiswa, sebagai contoh terlambat untuk mengikuti perkuliahan lanjutan akibat tidak tersedianya transportasi yang memadai di lingkungan universitas, tidak dapat naik shuttle bus yang disediakan oleh universitas karena terlambat sampai di lokasi pemberhentian bus. Sebagai sebuah solusi dari permasalahan ini adalah perancangan sebuah alat transportasi personal untuk mahasiswa yang selalu tersedia di lingkungan universitas untuk perjalanan didalam universitas.

Didalam penelitian ini akan dititik beratkan pada proses rancangan rekayasa (engineering design process) untuk mendapatkan sebuah desain awal (preliminary design) dari inovasi berbasiskan teknologi untuk mobilitas pribadi ramah lingkungan.

\section{METODE PENELITIAN}

Penelitian ini menggunakan Proses Desain Rekayasa (Engineering Design Process) dengan mengedepankan pendekatan terhadap pengguna, yang dikenal dengan istilah User-centered Approach 
(UcA) untuk dapat menghasilkan sebuah desain yang sesuai dengan kebutuhan pengguna (Usercentered Design). Selain itu juga di terapkan konsep Design Thinking (DT), dimana mendorong pola berpikir secara luas, divergence dan divergent concept thinking.

\section{HASIL DAN PEMBAHASAN}

Tahapan awal dari Engineering Design Process ini adalah etnografi, Etnografi adalah metode observasi yang telah digunakan secara tradisional dalam antropologi, tetapi telah semakin menarik minat dalam riset konsumen, baik dalam bidang akademis maupun industri.[13] Jenis etnography yang diterapkan dalam penelitian ini adalah keikutsertaaan peneliti menjadi peserta secara penuh (complete participant), dimana pada metode observasi ini peneliti melakukan observasi di lingkungan universitas dengan tanpa diketahui oleh kelompok yang sedang ditelitinya.

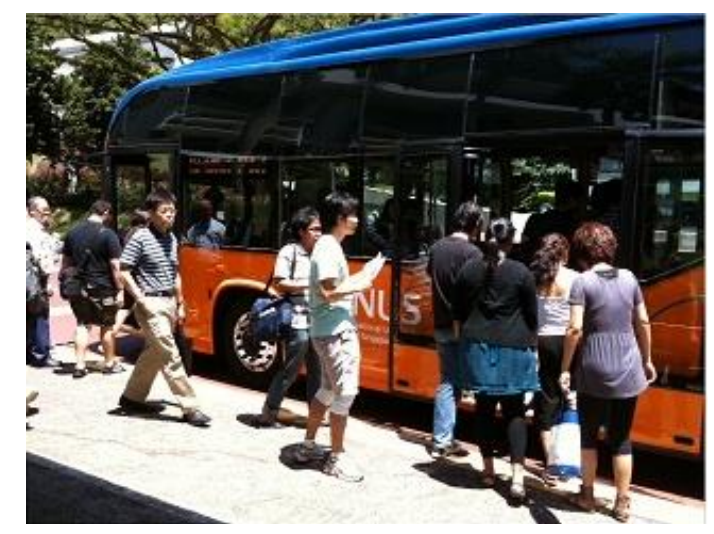

Gambar 1 Suasana pada pemberhentian bus

Pada tampilan gambar 1 adalah suasana pada pemberbentian bus di lingkungan universitas, penumpang yang terdiri civitas akademika bergegas untuk naik kedalam bus shuttle internal yang akan berkeliling sesuai jadwal yang sudah disediakan.

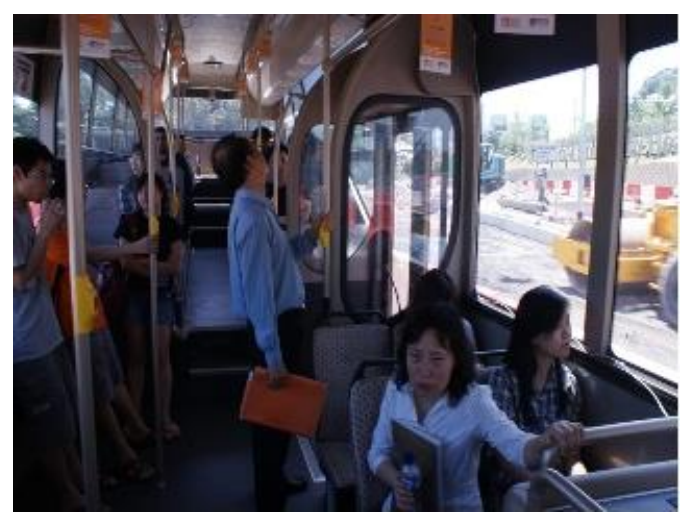

Gambar 2 Suasana di dalam shuttle bus
Pada gambar 2 menunjukkan suasana didalam shuttle bus, dapat dilihat bahwa penumpang membawa peralatan ada yang berdiri dan duduk.

Kemudian dilanjutkan dengan tahapan curahan gagasan terhadap permasalahan (brainstorming problems). Brainstorming adalah metode pengembangaan ide-ide yang dilakukan selama beberapa menit hingga satu jam dengan mengikuti aturan bahwa kritik terhadap suatu ide benar-benar dilarang, peserta didorong untuk menyampaikan ide secara bebas dan ide yang yang disampaikan harus tidak biasa Selama proses ini berlangsung akan dibimbing oleh seorang fasilisator [14] Pada gamabr 3 dapat dilihat brainstorming untuk permasalahan yang ditemukan didalam proses etnografi.

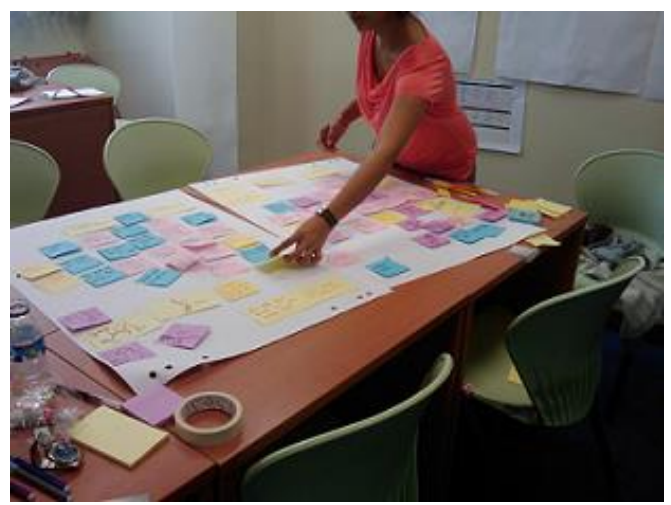

Gambar 3 Curahan gagasan dari hasil etnografi

Permasalahan-permasalahan yang ditemukan disampaiakan dengan tulisan atau gambar, dan selanjutkan dikelompokkan untuk memberikan gambaran terhadap permasalahan utama. Pada proses ini, dilakukan secara bersama anggota didalam kelompok, dengan memegang prinsip bahwa tidak ada gagasan yang salah, akan mendorong semua anggota di dalam kelompok untuk menyampaikan pendapatnya secara cepat dan lancer sesuai dengan waktu yang sudah ditentukan,

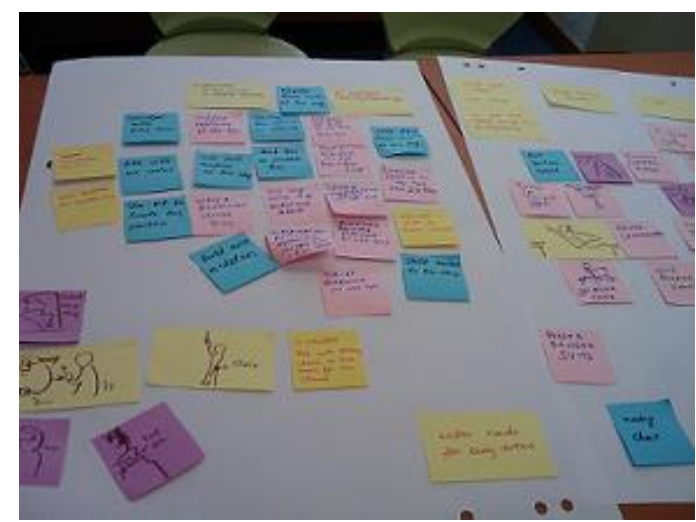

Gambar 4 Pengelompokan masalah yang ditemukan

53 Nusyirwan, Deny; Engineering Design Process Pada Perancangan Transportasi Personal Di Dalam Lingkungan Universitas 
Pada ahir tahapan brainstorming problems ini, telah ditemukan satu permasalahan utama dari hasil etnografi, yaitu mobilitas di dalam universitas.menjadi terhambat karena tidak tersedianya transportasi personal yang nyaman, tepat waktu dan ramah lingkungan di lingkungan universitas.

Pembuatan purwarupa sederhana sangat diperlukan untuk mengetahui rancangan awal (preliminary design). Pada tahapan ini, perancang akan memulai pembuatan purwarupa dari bahanbahan yang ekonomis dan fleksible, dengan maksud bahwa perubahan rancangan dapat dilakukan dengan mudah dan tidak akan memerlukan pembiayaan yang besar [17]. Pada gambar 5 menunjukkan hasil dari curahan gagasan didalam pembuatan model transportasi personal yang sesuai. Gagasan yang disampaikan bersifat bebas dan kreatif, semakin banyak purwarupa yang dihasilkan akan semakin mudah untuk mendapatkan sebuah solusi yang tepat. Pada proses ini menitik beratkan pada proses rancangan.
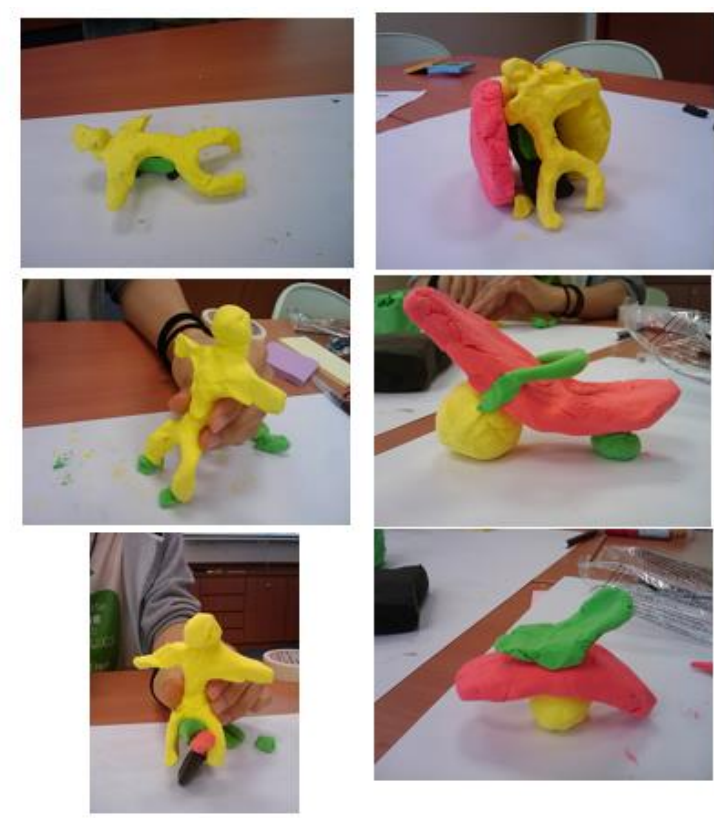

\section{Gambar 5Purwarupa dengan bahan yang ekonomi}

Setiap anggota kelompok bebas membuat purwarupa, kemudian menjelaskan terkait cara kerja dan teknologi yang dipergunkan oleh purwarupa yang sedang dikerjakannya. Setiap anggota akan memberikan tanggapan yang bermaksud untuk mendorong hasil rancangan tersebut menjadi lebih baik, prinsip menghormati dan tidak menyangkal sangat diperlukan didalam proses ini. Proses ini dapat dilakukan beberapa kali sehingga setiap anggota kelompok mensepakati satu rancangan yangn diteruskan pada tahapan leih detil.

Tahapan mensketsa dengan menggunakan alat tulis dan kertas yang dikenal dengan istilah sketching akan menyediakan komunikasi dan pengambilan keputusan yang lebih cepat pada tahap awal desain, dengan memberikan gabungan visual dan factual deskripsi untuk peningkatan evaluasi dan pemilihan konsep[15]. Tahapan awal ini adalah awal prosedur desain, dimana beberapa konsep sketsa disajikan untuk menangkap inspirasi sesaat, menafsirkan ide desain dan merekam kemajuan desain. [16]. Pada gambar 6 menampilkan hasil sketsa rancangan transportasi personal di lingkungan universitas.

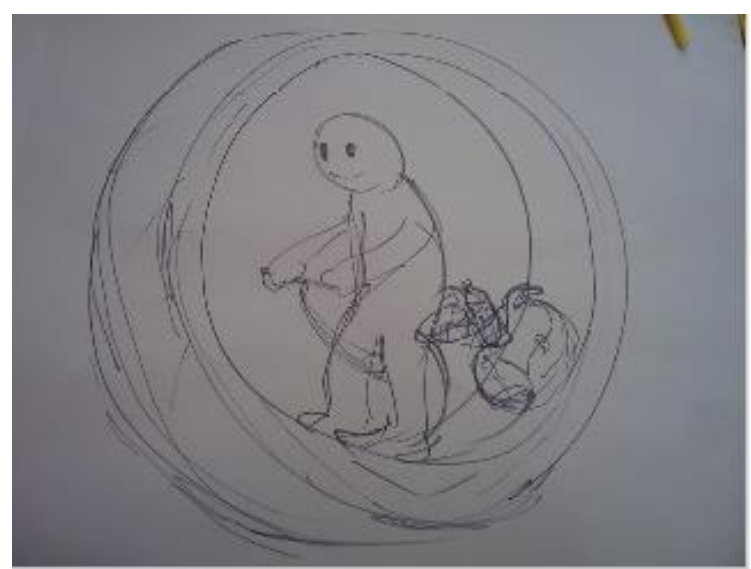

Gambar 6. Sketsarancangan transportasi personal

Untuk mendapatkan hasil rancangan yang lebih baik untuk dapat diobservasi lebih lanjut maka di rakit sebuah purwarupa sederhana dari bahan-bahan yang murah dan sederhana, seperti pena warna, isolaso, kertas dan stryrofoam. Dapat dilihat pada gambar 7.

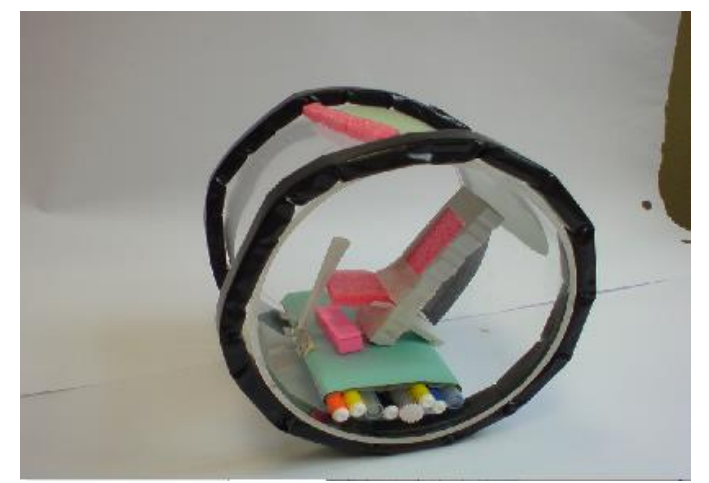

\section{Gambar 6 Purwarupa sederhana transportasi personal di lingkungan universitas}

Tahapan pengujian kegunaan dari konsep yang sedang dikerjakan dengan mempergunakan purwarupa sederhana adalah merupakan evaluasi awal terhadap inovasi yang dirancang dengan berbasis pengguna.Pada tahapan pengujian ini dapat dilakukan langsung kepada pengguna di luar 
kelompok atau seperti yang dilakukan pada penelitian ini, yaitu anggota kelompok melakukan simulasi dengan keadaaan yang sebenarnya, Permasalahan pertama yang dihadapi oleh seorang mahasiswa yang tertinggal shuttle bus, seperti pada gambar 8 .

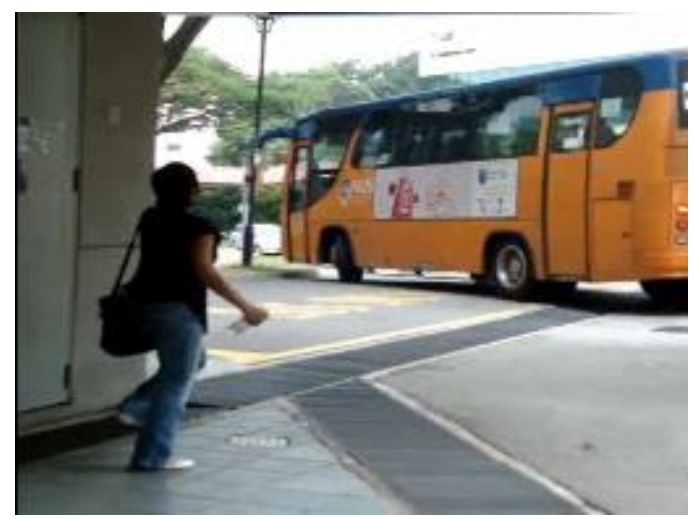

Gambar 7Mahasiswi tertinggal shuttle bus

Pada gambar 9, menunjukkan seoarang mahasiswi yang sedang menunggu shuttle bus untuk menghadiri perkuliahan lanjutan di fakultas lain.Mahasiswi tersebut merasa gelisah karena bus masih belum dating sedangkan perkuliahan akan segera dimulai.

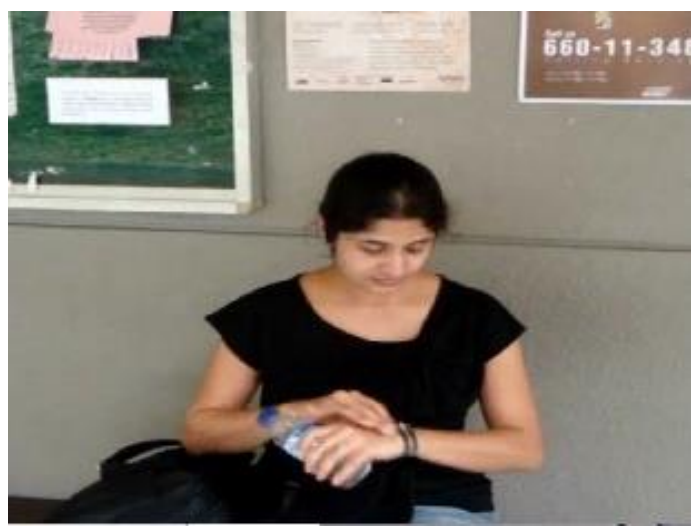

Gambar 8 Mahasiswi menunggu shuttle bus

Pada gambar 10 menampilkan mahasiswi sedang menggunakan purwarupa transportasi personal ramah lingkungan yang merupakan proses pengujian keguanaan dan mendapatkan pengalaman pengguna.

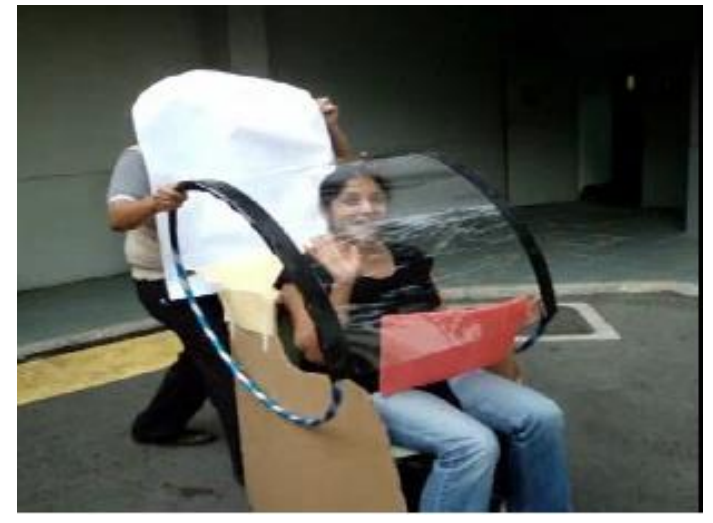

Gambar 9 Mahasiswi menggunakan purwarupa transportasi personal ramah lingkungan

Untuk permasalahan kedua yang dihadapi oleh mahasiswa adalah tidak nyaman ketika akan bepergian menghadiri perkuliahan. Pada gambar 10 menampilkan seorang mahasiswa yang sedang menggunakan sepeda konvensional untuk menghadirkan perkuliahan. mahasiswa mengalami kelelahan setelah sampai di tujuan karena lintasan yang dilalui naik turun dan masih menggunakan tenaga manusia untuk menggerakkan roda sepeda.

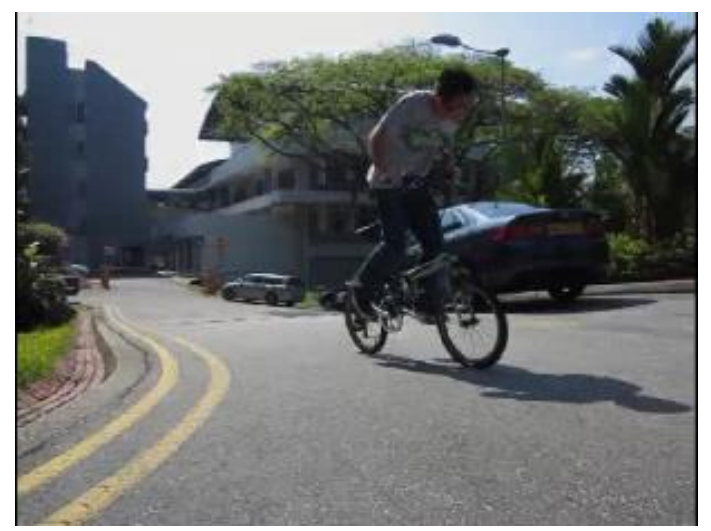

Gambar 10 Mahasiswi menggunakan sepeda konvensional untuk menghadiri perkuliahan

Evaluasi awal dari pengujian kegunaan ini diperlukan untuk menghindari desain yang buruk sehingga akan dapat berdampak secara langsung dan tidak langsung yang akan merugikan persuhaaan. Adapun dampak langsung seperti menerima panggilan dari pengguna untuk layanan dan keluhan, dan juga melalui barang yang dikembalikan. Untuk dampak secara tidak langsung melalui pengurangan penjualan karena penerimaan konsumen yang buruk dan citra produk yang buruk, dan melalui dampak lanjutan dari persepsi konsumen terhadap perusahaan diri [18] 


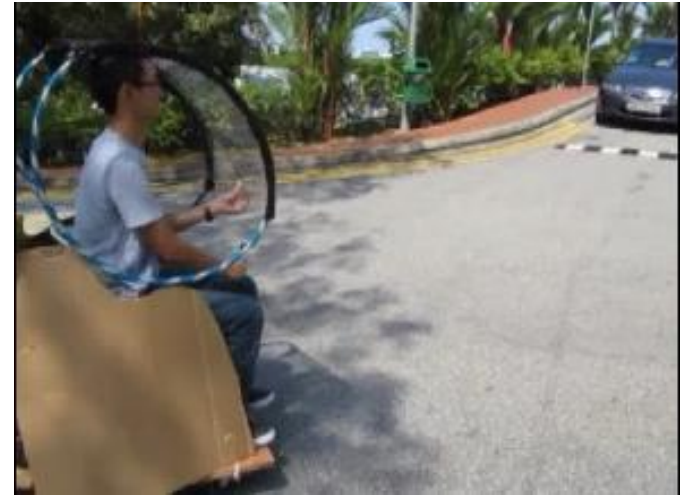

Gambar 11 Mahasiswa menggunakan purwarupa transportasi personal untuk menggantikan sepeda konvensional.

Pengalaman pengguna (user experience) untuk mendapatkan masukan-masukan dari calon pengguna yang akan dipergunakan untuk memperbaiki rancangan sebelumnya. Pengembangan produk tidak lagi hanya tentang mengimplementasikan fitur dan menguji kegunaannya, tetapi juga tentang mendesain produk yang menyenangkan dan mendukung kebutuhan dan nilai-nilai dasar manusia. Dengan demikian, pengalaman pengguna dalam tahapan EDP harus menjadi perhatian utama pengembangan produk [19]

\section{KESIMPULAN}

Pada penelitian mengenai perancangan transportasi personal yang sesuai untuk lingkungan universitas menggunakan Engineering Design Process, telah menemukan permasalahan transportasi personal sebagai penghambat mobilitas dan aktivitas mahasiswa. Oleh sebab itu didalam penelitian ini, dilakukan tahapan observasi sebagai awal pengumpulan data dan informasi, yang dilanjutkan dengan tahapan lainnya sehingga melakukan pengujian purwarupa. Pada ahirnya inovasi teknologi berupa transportasi personal ramah lingkungan yang dihasilkan adalah merupakan solusi terhadap permasalahan yang ada di lingkungan universitas.

\section{UCAPAN TERIMA KASIH}

Terima kasih kepada rekan di jurusan teknik elektro Universitas Maritim Raja Ali Haji (UMRAH) yang telah memotivasi untuk melakukan penelitian, redaksi journal Machine Universitas Bangka Belitung yang telah memberikan kesempatan untuk publikasi.dan teman-teman di National University of Singapore.

\section{DAFTAR PUSTAKA}

[1] D. Magliocchetti, M. Gielow, F. De Vigili, G. Conti dan R. De Amicis, "A Personal Mobility Assistant based on Ambient Intelligence to Promote Sustainable Travel Choices", Procedia Computer Science 5 (2011) 892-899, Elsevier Ltd., 2013

[2] M. Boero, M. Garré, J. Fernandez, S. Persi, D. Quesada dan M. Jakob, "MyWay personal mobility : from journey planners to mobility resource management", Transportation Research Procedia 14 ( 2016 ) 1154 - 1163, Elsevier Ltd., 2016

[3] T. Jones, L. Harms dan E. Heinenc, "Motives, perceptions and experiences of electric bicycle owners and implications for health, wellbeing and mobility", Journal of Transport Geography 53 (2016) 41-49, Elsevier Ltd., 2016

[4] N. Bergman, "Stories of the future: Personal mobility innovation in the United Kingdom", Energy Research \& Social Science 31 (2017) 184-193, Elsevier Ltd., 2017

[5] L. Frändberg dan B. Vilhelmson, "More or less travel: personal mobility trends in the Swedish population focusing gender and cohort", Journal of Transport Geography 19 (2011) 1235-1244, Elsevier Ltd., 2011

[6] S. Gössling, S. Cohen, J. Higham, P. Peeters dan E. Eijgelaarg, "Desirable transport futures", Transportation Research Part D: Transport and Environment Volume 61, Part B, June 2018, Pages 301-309, Elsevier Ltd., 2018

[7] L.H. Björnsson, S. Karlsson, F. Sprei, "Objective functions for plug-in hybrid electric vehicle battery range optimization and possible effects on the vehicle fleet", Transportation Research Part C 86 (2018) 655-669, Elsevier Ltd., 2018

[8] S. Hardmana et. al, "A review of consumer preferences of and interactions with electric vehicle charging infrastructure", Transportation Research Part D 62 (2018) 508-523, Elsevier Ltd., 2018

[9] T. Gnanna et. al, "Fast charging infrastructure for electric vehicles: Today's situation and future needs", Transportation Research Part D 62 (2018) 314-329, Elsevier Ltd., 2018

$[10] \mathrm{K} . \quad T$. Ulrich, "Estimating the technology frontier for personal electric vehicles", Transportation Research Part C 13 (2005) 448462, Elsevier Ltd., 2006

[11]W. Kempton dan S. E. Letendre, "Electric Vehicles as a new power source for electric utilities", Trmspn \&S.-D, Vol. 2, No. 3, pp. 157-175, 1997, Elsevier Science Ltd., 1997 